\title{
Oito Nações Europeias Colaboram na Investigação em Catálise para a Sustentabilidade
}

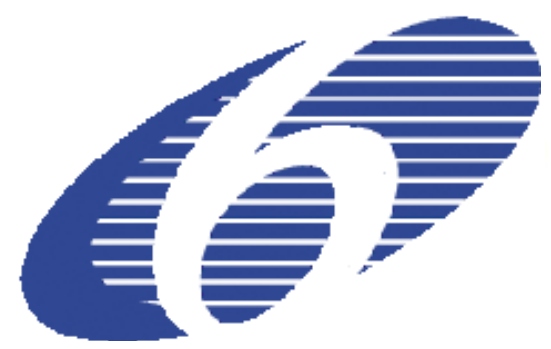

Foram criados seis projectos transnacionais na área da catálise para a sustentabilidade através da ACENET (Applied Catalysis European NETwork), a ERANET para a Catálise Aplicada na Europa. Os projectos têm um objectivo comum: alargamento do conhecimento e capacidade Europeus na área chave do fabrico catalítico eficiente, do ponto de vista energético e do carbono, de combustíveis e produtos químicos. Cada projecto corresponde a uma colaboração interdisciplinar indústria-universidade envolvendo pelo menos três países. Ministérios de Investigação e agências de financiamento de oito Estados Membros da UE disponibilizaram 4,5 milhões de euros de fundos nacionais para esta iniciativa; ao todo, serão financiados 21 grupos de investigação universitários e da indústria, havendo ainda a contribuição de 14 parceiros industriais associados para a investigação.

Os investigadores dos consórcios envolvidos nestes projectos desenvolverão o seu trabalho em aspectos tão variados como a produção de hidrogénio a partir de bioalcoóis ou a conversão de biomassa sólida em combustíveis renováveis e produtos químicos, para desenvolverem uma tecnologia que permita a conversão a baixa temperatura dos gases de A $63^{a}$ sessão da Assembleia Geral da
Nações Unidas declarou 2011 como o Ano Internacional da Química. A resolução foi apresentada pela Etiópia, com o patrocínio formal de mais de 35 países e o apoio de muitos outros. O texto da resolução, apresentado no contexto da Agenda para o Desenvolvimento Sustentável (acessível em http:// www.un.org/ga/second/63/proposals-
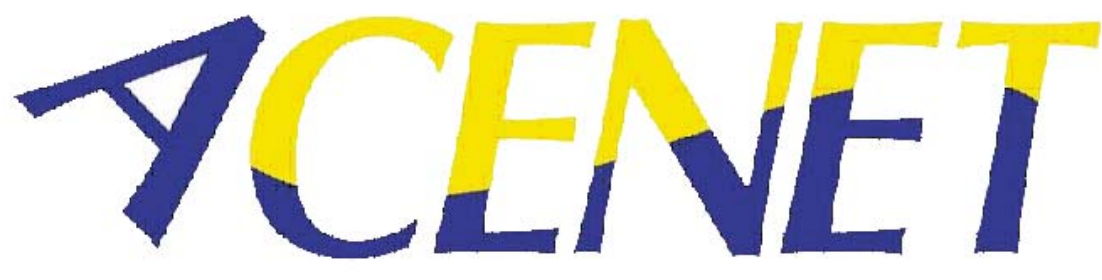

efeito de estufa, metano e dióxido de carbono, em monóxido de carbono e hidrogénio, que são matérias primas importantes para a produção de hidrocarbonetos líquidos. Pretende-se fortalecer a posição da Europa num ambiente global de crescente competitividade, em linha com os objectivos da Agenda de Lisboa.

Os seis projectos foram seleccionados de um conjunto de 30 propostas recebidas, com base nos critérios de excelência científica, impacto potencial numa indústria sustentável e a qualidade do consórcio. Foram também estabelecidos pela ACENET planos de monitorização e de governação dos projectos.

As tecnologias catalíticas são usadas no fabrico de combustíveis, produtos químicos e farmacêuticos, assim como na produção de alimentos, produtos de limpeza e no controle de poluição. A Catálise Aplicada é uma ciência altamente interdisciplinar que engloba a química e a engenharia química mas também a ciência de materiais, engenharia de reacções e outras áreas. Tem um enorme potencial para abordar muitas áreas da actividade socio-económica e muitos dos desafios que se colocam actualmente à Europa, tais como, a sustentabilida-

\section{Ano Internacional da Química}

list.shtml), reconhece que o conhecimento que a humanidade possui da natureza dos materiais do nosso mundo assenta, em particular, no nosso conhecimento de química. Realça que a educação sobre e em torno da química é essencial para abordar os desafios que se apresentam actualmente à humanidade, como as alterações climáticas globais, providenciando fontes de e a produção sustentável, energias renováveis e protecção ambiental. A Catálise Aplicada tem, por isso, um enorme impacto na prosperidade económica e social mundial e é uma tecnologia vital para a Europa.

ACENET, a Rede Europeia de Catálise Aplicada ("Applied Catalysis European NETwork") fundada em 2004 , é um excelente exemplo do esquema ERANET, criado pela Comissão Europeia no contexto do Sexto Programa Quadro para melhorar a coordenação das actividades nacionais de investigação entre os Estados Membros. Ministérios e agências de França, Alemanha, Grécia, Irlanda, Itália, Holanda, Polónia, Portugal, Espanha e Reino Unido colaboram no Programa ACENET, que continuará até 2010. Durante os próximos dois anos haverá uma segunda chamada de projectos de investigação transnacionais, desenvolvimentos na rede de programas de educação e uma iniciativa conjunta para um plano ("roadmap") que tem por objectivo fortalecer a colaboração entre os ministérios e as agências de financiamento nacionais.

Adaptado do Press Release da ACENET de Outubro.

Em www.acenet.net está disponível informação adicional.

sustentáveis de água potável, alimentos e energia, e a manutenção de um meio ambiente adequado ao bem estar de toda a humanidade. A IUPAC e a UNESCO lançarão em breve um press release conjunto. Espera-se que a celebração e a promoção da química que se aproximam permitam realçar o seu papel positivo nas nossas vidas. Há desafios que só a química pode enfrentar. 